\title{
Strikingly malformed host morphology: Myrmica rugulosa Nyl. and Myrmica sabuleti Mein. (Hymenoptera: Formicidae) parasitised by mermithid nematodes
}

\author{
Wojciech Czechowski, Wiesława CzEchowska and Alexander RADCHENKo \\ Laboratory of Social and Myrmecophilous Insects, Museum and Institute of Zoology, Polish Academy of Sciences, \\ Wilcza 64,00-679 Warsaw, Poland; e-mails: wcz@miiz.waw.pl,w.czechowska@miz.waw.pl, \\ agradchenko@hotmail.com
}

\begin{abstract}
Mermithid nematode infestation of Myrmica rugulosa Nyl. and $M$. sabuleti Mein. is reported, and parasitogenic morphological anomalies of these two ant species are described for the first time. Two infected $M$. rugulosa males and a female worker-like individual of $M$. sabuleti were found outside their nests in the Pieniny Mts (southern Poland). The latter individual was recognised belonging to the gynaecoid mermithergate parasitogenic category caused by the mermithid parasitism. Mermithogenic malformation of the infected $M$. sabuleti female is discussed in the context of its developmental origin. Emphasis is also placed on possible taxonomic difficulties in the determination of Myrmica Latr. specimens infected by the mermithids as well as the risk of erroneous descriptions of taxa based on such parasitogenic forms.
\end{abstract}

Key words: ants, Myrmica rugulosa, Myrmica sabuleti, parasites, Nematoda, Mermithidae, morphology, teratology

\section{INTRODUCTION}

Parasitic nematodes of the family Mermithidae develop in the haemocoele of ants, bringing on various modifications in the morphology, anatomy and physiology of the parasitised (mermithised) individuals (for a review see Passera 1975 and e.g. Kloft 1949, Passera 1974, Espadaler \& Riasol 1983). Infestation of host ants occurs per os in either their larval or imaginal stage, and its morphological effects in adult ants are particularly conspicuous if the host was parasitised in the early phase of its larval development (Kutter 1958). In that case, modifications are not restricted to a distinctively swollen gaster of the host caused by the very presence of the large-sized parasite, but infestation may also induce advanced malformations, e.g. relatively exaggerated body parts and oddish indices. As a result morphologically modified worker-like individuals (called mermithergates), intercaste (sensu Heinze 1998) females (called gynaecoid mermithergates), and more or less modified (including brachypterous) sexuals, both gynes and males (mermithogynes and mermithaners respectively) come into being (e.g. Wheeler 1928, 1937, Gösswald 1929, Passera 1974; for review see Passera 1975). In species with a dimorphic worker caste, intermediate forms between the ordinary worker and the soldier may also develop (e.g. Vandel 1930, Passera 1976).

Mermithid nematodes infest ants of several taxa; for a survey see Passera (1975). Several species of the genus Myrmica Latr., M. rubra (L.), M. ruginodis Nyl., M. rugulosa Nyl., $M$. scabrinodis Nyl., M. schencki Viereck, and $M$. gallienii Bondr., are known to be mermithised (Hagmeier 1912, Gösswald 1930, 1938, Vandel 1930, Kloft 1949, 1950, Czechowski et al. 2007, Csősz 2008). In the majority of cases, infested Myrmica individuals described to date showed only minor morphological modifications (apart from distended gasters). Gösswald (1930) did not find any developmental deformations in the external body structure of mermithised $M$. rubra, $M$. ruginodis, $M$. rugulosa, and $M$. scabrinodis, including both workers 
and sexuals. Vandel (1930) noted the presence of a medial ocellus on an otherwise normal head of one M. rubra worker, and Kloft $(1949,1950)$ reported on a brachypterous $M$. ruginodis gyne. [In the above quoted papers by Gösswald, Kloft and Vandel, in accordance with the taxonomy of the time, $M$. rubra (L.) and M. ruginodis Nyl. were named $M$. laevinodis $\mathrm{Nyl}$. and M. rubra (L.) respectively]. Only Czechowski et al. (2007) described in detail strikingly altered morphology (based on morphometrics, sculpture and pilosity) of mermithised worker-like individuals of $M$. rubra, and Csősz (2008) evidenced the ontogenic origin of infected $M$. scabrinodis and $M$. gallienii individuals.

As for males of the genus Myrmica, only one M. scabrinodis mermithised individual has been known to date (Gösswald 1930). The present paper describes for the first time morphological mermithogenic anomalies in $M$. rugulosa males and is the second report on mermithised Myrmica males in general. This paper also gives the first description of the mermithogenic anomaly of a worker-like female individual of $M$. sabuleti Mein.

\section{STUDY AREA, MATERIAL AND METHODS}

Two infected males of $M$. rugulosa and a single worker-like individual of $M$. sabuleti were collected in the Pieniny Mts (Central Western Carpathians, southern Poland) on 28 August, 1997. They were encountered outside their nests (the nests were not found) on a road along a stream in the Gorczyński Gorge (Wąwóz Gorczyński) close to the place where a markedly mermithised colony of $M$. rubra was found (see Czechowski et al. 2007). An autopsy of the malformed ants, both $M$. rugulosa and $M$. sabuleti, revealed the presence of mermithid nematodes in their gasters.

The morphology of the infested individuals was compared with that of non-infested ants using selected (relevant to the cases under discussion) standard morphometrics (measurements and indices) employed in taxonomy of the genus Myrmica (see Radchenko \& Elmes 1998, 1999). The measurements, made with Olympus SZX-12 stereoscopic microscope to an accuracy of one hundredth of a millimetre, were as follows:

$\mathrm{HL}$ - maximum length of head in dorsal view, measured in a straight line from anteriormost point of clypeus (including any carinae or rugae, if they protrude over the anterior margin) to mid-point of occipital margin;

HW - maximum width of head in dorsal view behind (above) eyes;

SL - maximum straight-line length of antennal scape in profile, from its articulation with condylar bulb to proximal edge of scape;

FW - minimum width of frons between frontal lobes (in M. sabuleti individuals);

FLW - maximum width between external borders of frontal lobes (in $M$. sabuleti individuals);

PL - maximum length of petiole from above, measured from posterio-dorsal margin of petiole to its anterior edge at articulation with propodeum; petiole should be positioned so that measured points lay on the same plane;

PW - maximum width of petiole from above;

$\mathrm{PH}$ - maximum height of petiole in profile, from uppermost point of petiolar node, perpendicularly to imaginary line between anterio-ventral (just behind sub-petiolar process) and posterio-ventral points of petiole;

PPL - maximum length of postpetiole from above, from its anterior to posterior margins;

PPW - maximum width of postpetiole from above;

PPH - maximum height of postpetiole in profile, from its uppermost to lowermost points, perpendicularly to linear component of lateral postpetiolar suture; 
ESL - maximum length of propodeal spine in profile, along spine, from its tip to deepest point of propodeal constriction at base of spines (in $M$. sabuleti individuals);

ESD - distance between tips of propodeal spines from above (in $M$. sabuleti individuals);

HTL - maximum length of hind tibia, from junction with femur to junction with first tarsal joint (in M. rugulosa males);

$\mathrm{AL}$ - diagonal length of alitrunk in profile, from anterio-upper margin of pronotum to posterior margin of propodeal lobes (in $M$. rugulosa males), or from the neck shield to posterior margin of propodeal lobes (in M. sabuleti individuals);

$\mathrm{AH}$ - height of alitrunk, from upper level of mesonotum, perpendicularly to level of lower margin of mesopleura (in $M$. rugulosa males);

PNW - maximum width of pronotum from above (in $M$. sabuleti individuals);

$\mathrm{ScW}$ - maximum width of scutum from above (in M. rugulosa males);

$\mathrm{Sc}+\mathrm{SctL}$ - total length of scutum and scutellum from above (in M. rugulosa males).

Basing on the above measurements, the following indices were calculated:

cephalic index - HL/HW;

frontal index - FW/HW (for M. sabuleti);

frontal lobe index - FLW/FW (for $M$. sabuleti);

scape indices - SL/HL, SL/HW (both for $M$. sabuleti);

petiolar indices - PL/PH, PL/PW, PL/HW (for M. rugulosa), PW/HW;

post-petiolar indices - PPL/PPH, PPH/PPW (for $M$. rugulosa), PPW/PW, PPW/HW;

alitrunk indices - AL/AH, AL/HW, AH/HW (for M. rugulosa);

scutum index - Sc+SctL/ScW (for M. rugulosa).

For comparative purposes, museum specimens of $M$. rugulosa males and $M$. sabuleti workers ( $n=10$ in each case) from the collection of Museum and Institute of Zoology PAS, Warsaw, were used; the comparative individuals of both $M$. rugulosa and $M$. sabuleti had been collected in the Pieniny Mts. Each of the M. sabuleti worker specimens represented a separate nest series. The same can not be said about the $M$. rugulosa males, as they were caught during their nuptial flights.

Colour photos of a mermithised male of M. rugulosa were taken with a camera IC3D and a Leica MZ16 stereoscopic microscope. SEM photographs (Hitachi S-3400N) of the parasitised $M$. sabuleti specimen and its non-infested counterpart were also taken following routine preparation of materials.

\section{RESULTS}

The most clearly visible feature of the mermithised males of $M$. rugulosa was their brachyptery; both pairs of their wings were vestigial (Figs 1,2). As for their morphometrics, the two infected males differed considerably from each other in particular morphometric characteristics (Table 1). On the other hand, some general differences were noticeable between them and the normal conspecific males. Differences in the mean values of six of the 14 measurements, and six of the 15 indices obtained for infested and non-infested individuals were distinct. The mermithised males were smaller (not taking into account their mechanically distended and, consequently, also lengthened, gasters), mainly because of a distinctly shortened alitrunk. They had shortened legs, a narrowed scutum and shortened scutum and scutellum. Their alitrunks were relatively higher than those of uninfected males (see Table 1 for details).

The mermithised individual of M. sabuleti, besides its enlarged gaster (Fig. 3), had three ocelli present (a well developed median ocellus and weakly developed lateral ones; Fig. 4) and no suberect hairs on the head margins above the eyes (Fig. 5), unlike normal conspecific workers, which have no ocelli and have long suberect hairs on head margins (Fig. 6). The mermithised ant also had outlined scutum and scutellum (Fig. 7). Interpretation of comparative morphometric data for the infested and non-infested specimens is difficult as there was only 
one mermithised specimen found of unclear caste status (see Discussion). Anyway, there were a number of distinct differences besides the infested individual being bigger (not including the distended gaster) than its non-infested counterparts. Basing on the values of indices, evident effects of mermithisation that could be recognised comprise a much wider frons, and raised and widened petiole and postpetiole (Table 2, Figs 5-8).

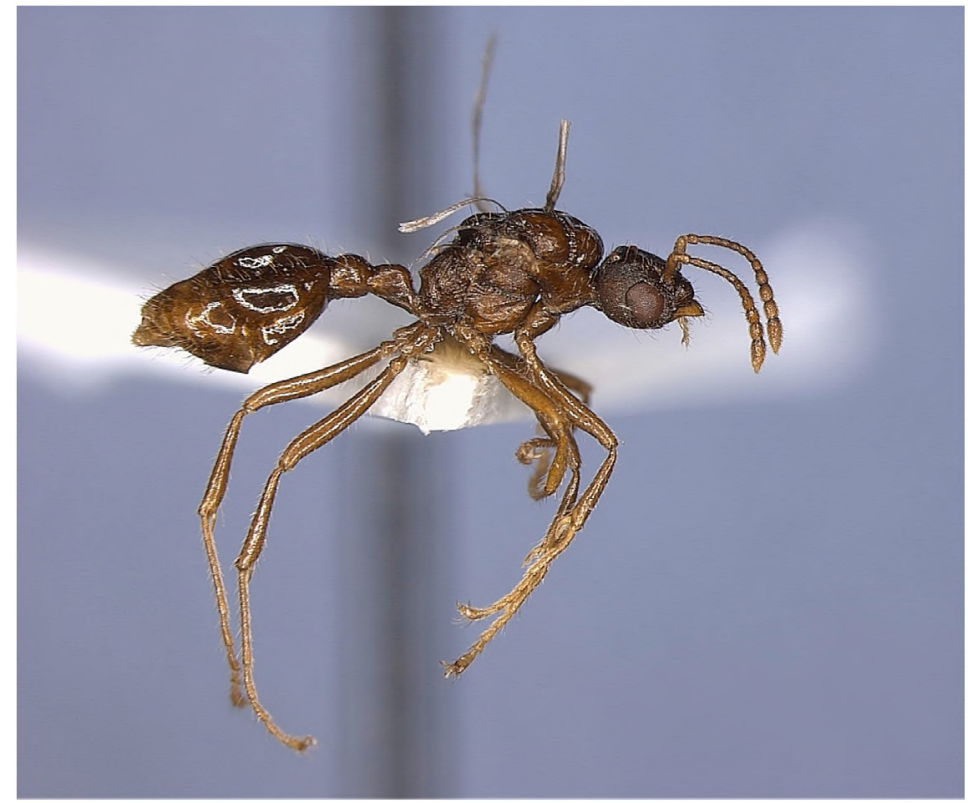

Fig. 1. General appearance of the mermithised male of $M$. rugulosa in profile.

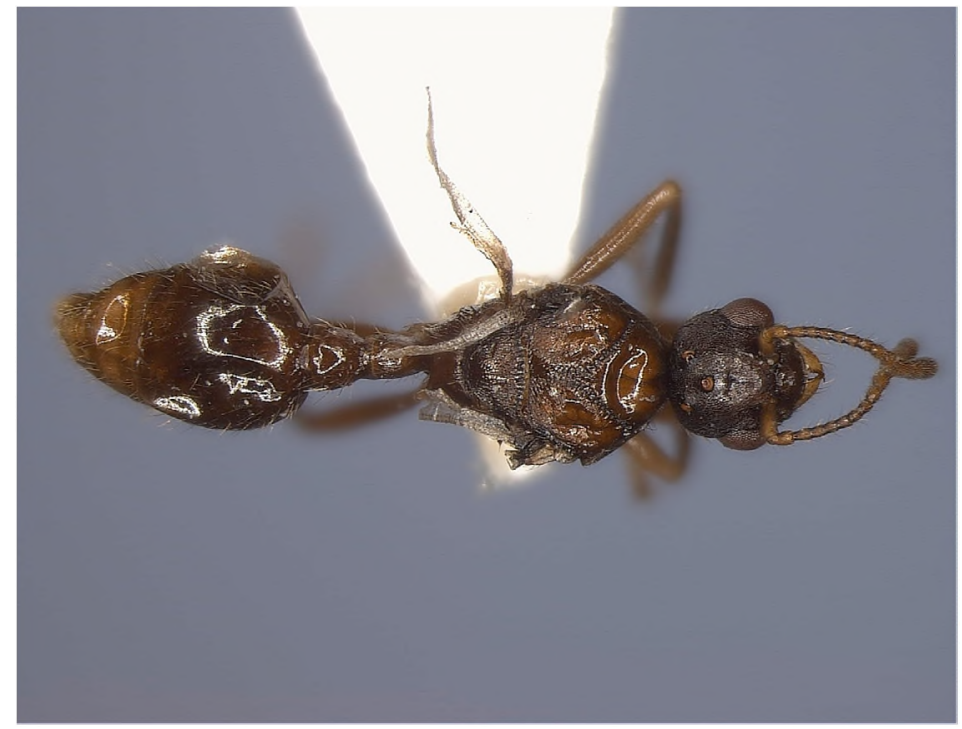

Fig. 2. General appearance of the mermithised male of $M$. rugulosa from above. 


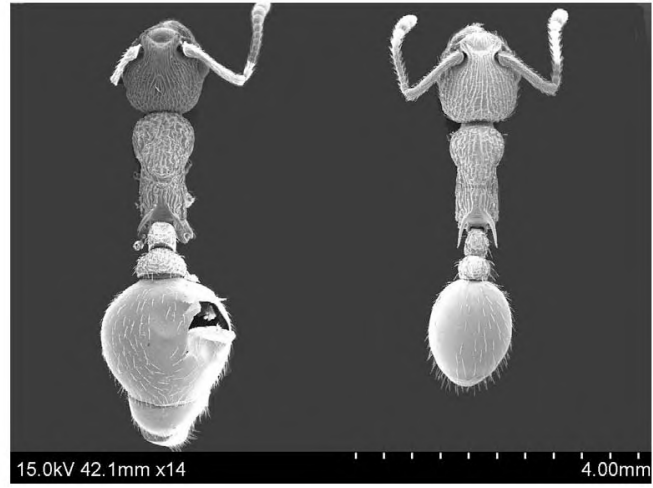

Fig. 3. General appearance of the mermithised individual of $M$. sabuleti (on the left) and a conspecific non-infested worker (on the right).

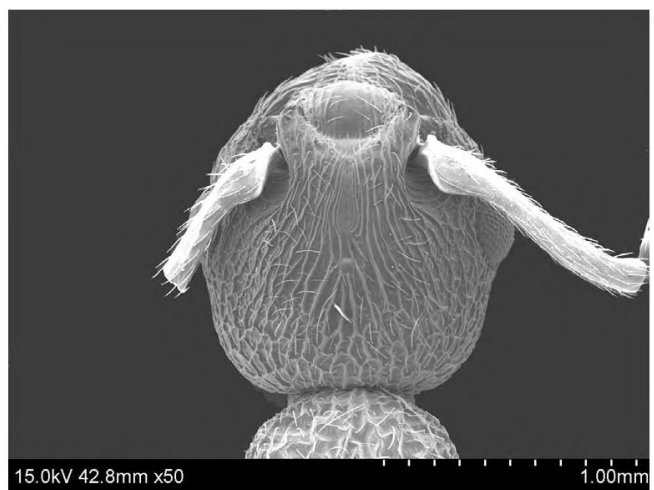

Fig. 5. Head of the mermithised individual of M. sabuleti.

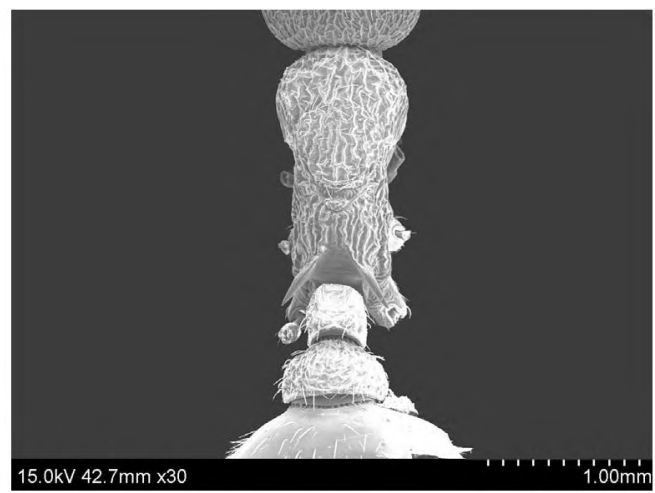

Fig. 7. Alitrunk and petiole of the mermithised individual of $M$. sabuleti.

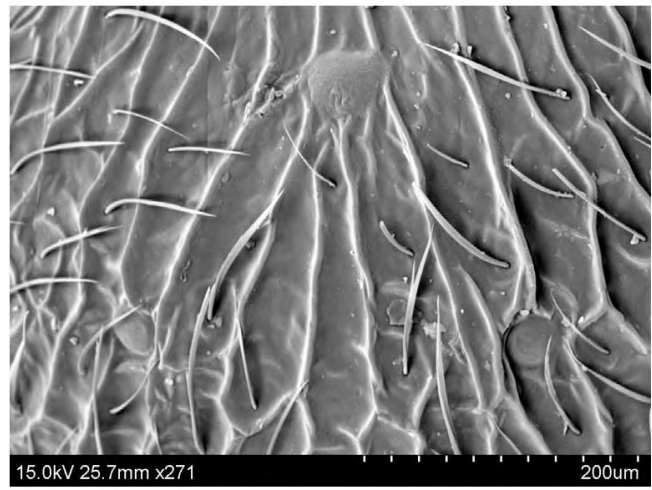

Fig. 4. Part of the frons of the mermithised individual of $M$. sabuleti with three ocelli visible.

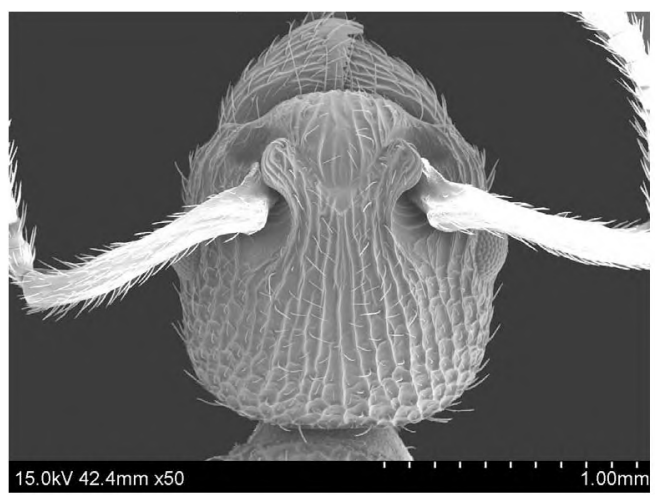

Fig. 6. Head of a non-infested worker of $M$. sabuleti.

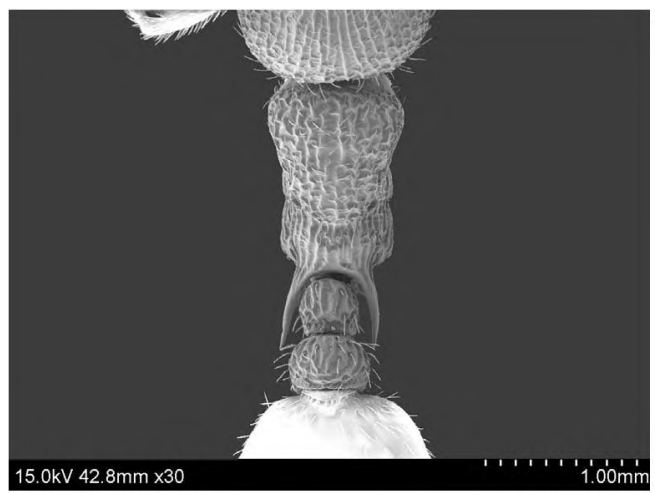

Fig. 8. Alitrunk and petiole of a non-infested worker of M. sabuleti.

\section{DISCUSSION}

The above descriptions of mermithised individuals of $M$. rugulosa, and especially that of M. sabuleti, confirm the earlier data on M. rubra (Czechowski et al. 2007) demonstrating that infected Myrmica individuals might exhibit alternative phenotypes and differ from uninfected 
individuals of the species even in key taxonomic features. Mermithid-infested M. rugulosa males (mermithaners, according to Wheeler's 1928 terminology), reported here for the first time, although brachypterous and remarkably smaller than uninfected males of this species, were still not modified to a degree making it difficult to determine their taxonomic status.

Table 1. Morphometric characteristics of the mermithised and non-mermithised males of $M$. rugulosa: the means $( \pm \mathrm{SD})$ and ranges of values of the measurements and indices; values of the features which for the infested individuals are out of the range of variability of the uninfected individuals, or at least their means differ distinctly, are bolded.

\begin{tabular}{|c|c|c|c|}
\hline & Feature & Infested $(n=2)$ & Non-infested $(\mathrm{n}=10)$ \\
\hline \multirow{14}{*}{ 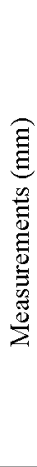 } & HL & $0.735(0.75$ and 0.72$)$ & $0.776 \pm 0.028(0.75-0.84)$ \\
\hline & HW & $0.720(0.74$ and 0.70$)$ & $0.757 \pm 0.023(0.72-0.80)$ \\
\hline & SL & $0.295(0.28$ and 0.31$)$ & $0.293 \pm 0.009(0.28-0.30)$ \\
\hline & PL & $0.420(0.42$ and 0.42$)$ & $0.458 \pm 0.024(0.43-0.51)$ \\
\hline & PW & $0.260(0.26$ and 0.26$)$ & $0.272 \pm 0.019(0.24-0.30)$ \\
\hline & PH & $0.315(0.31$ and 0.32$)$ & $0.341 \pm 0.014(0.33-0.37)$ \\
\hline & PPL & $0.330(0.33$ and 0.33$)$ & $0.324 \pm 0.015(0.30-0.35)$ \\
\hline & PPW & $0.420(0.38$ and 0.46$)$ & $0.413 \pm 0.017(0.40-0.45)$ \\
\hline & PPH & $0.385(0.35$ and 0.42$)$ & $0.401 \pm 0.019(0.36-0.43)$ \\
\hline & HTL & $0.855(0.88$ and 0.83$)$ & $1.151 \pm 0.049(1.08-1.25)$ \\
\hline & $\mathbf{A L}$ & $1.565(1.60$ and 1.53$)$ & $2.143 \pm 0.102(1.98-2.33)$ \\
\hline & AH & $0.980(1.03$ and 0.93$)$ & $1.259 \pm 0.084(1.15-1.40)$ \\
\hline & ScW & $0.860(0.97$ and 0.75$)$ & $1.149 \pm 0.062(1.08-1.28)$ \\
\hline & Se+SetL & $1.115(1.13$ and 1.10$)$ & $1.529 \pm 0.085(1.45-1.70)$ \\
\hline \multirow{15}{*}{ 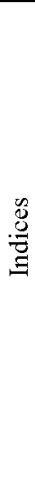 } & $\mathrm{HL} / \mathrm{HW}$ & $1.030(1.02$ and 1.04$)$ & $1.027 \pm 0.018(1.00-1.05)$ \\
\hline & $\mathrm{SL} / \mathrm{HL}$ & $0.395(0.37$ and 0.42$)$ & $0.384 \pm 0.013(0.36-0.41)$ \\
\hline & $\mathrm{SL} / \mathrm{HW}$ & $0.410(0.38$ and 0.44$)$ & $0.393 \pm 0.016(0.37-0.42)$ \\
\hline & $\mathrm{PL} / \mathrm{PH}$ & $1.330(1.36$ and 1.30$)$ & $1.334 \pm 0.051(1.22-1.42)$ \\
\hline & $\mathrm{PL} / \mathrm{PW}$ & $1.620(1.62$ and 1.62$)$ & $1.741 \pm 0.133(1.56-1.96)$ \\
\hline & $\mathrm{PL} / \mathrm{HW}$ & $0.585(0.57$ and 0.60$)$ & $0.607 \pm 0.030(0.56-0.65)$ \\
\hline & $\mathrm{PW} / \mathrm{HW}$ & $0.370(0.36$ and 0.38$)$ & $0.361 \pm 0.021(0.33-0.40)$ \\
\hline & PPL/PPH & $0.880(0.96$ and 0.80$)$ & $0.807 \pm 0.023(0.78-0.86)$ \\
\hline & PPH/PPW & $0.915(0.92$ and 0.91$)$ & $0.967 \pm 0.024(0.92-1.00)$ \\
\hline & $\mathrm{PPW} / \mathrm{PW}$ & $1.580(1.42$ and 1.72$)$ & $1.514 \pm 0.067(1.41-1.64)$ \\
\hline & PPW/HW & $0.585(0.51$ and 0.66$)$ & $0.548 \pm 0.021(0.51-0.60)$ \\
\hline & AL/AH & $1.470(1.55$ and 1.39$)$ & $1.713 \pm 0.025(1.67-1.75)$ \\
\hline & AL/HW & $2.175(2.16$ and 2.19$)$ & $2.820 \pm 0.077(2.72-2.94)$ \\
\hline & $\mathbf{A H} / \mathbf{H W}$ & $1.360(1.39$ and 1.33$)$ & $1.647 \pm 0.057(1.57-1.74)$ \\
\hline & $\mathrm{Sc}+\mathrm{SctL} / \mathrm{ScW}$ & $1.310(1.16$ and 1.46$)$ & $1.328 \pm 0.016(1.30-1.35)$ \\
\hline
\end{tabular}

The problem of the taxonomic status of the singly found worker-like individual was much more difficult. First, only its membership of the scabrinodis-group (see Radchenko \& Elmes 2004) was unquestionable, but the specimen did not look like any known member of this group in morphometric terms. Its determination was partly accomplished by elimination. The myrmecofauna of the Polish part of the Pieniny Mts has been extensively investigated. Seven species of the scabrinodis-group occur there: M. rugulosa, M. hellenica Finzi, $M$. specioides Bondr., M. scabrinodis, M. sabuleti, M. lonae Finzi, and the socially parasitic $M$. hirsuta Elmes (Czechowski et al. 2002). The specimen under discussion, ultimately identified as M. sabuleti, basing on a combination of its morphological features, and current understanding of trends of mermithogenic modifications in M. rubra (see Czechowski et al. 2007), could also be recognised as $M$. scabrinodis (a form with a well-defined scape lobe). The decisive argument in favour of $M$ sabuleti was that, in the Gorczyński Gorge, where this debatable individual was caught, $M$. sabuleti occurs commonly and $M$. scabrinodis has never been found despite the intense myrmecological survey. 
Table 2. Morphometric characteristics of the mermithised individual of $M$. sabuleti and of non-infested conspecific workers: the means $( \pm$ SD) and ranges of values of the measurements and indices; values of the features which for the infested individual are out of the range of variability of the uninfected individuals are bolded.

\begin{tabular}{|c|c|c|c|}
\hline & Feature & $\begin{array}{c}\text { Infested } \\
(\mathrm{n}=1)\end{array}$ & $\begin{array}{l}\text { Non-infested } \\
(\mathrm{n}=10)\end{array}$ \\
\hline \multirow{15}{*}{ 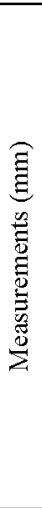 } & HL & 1.33 & $1.140 \pm 0.074(1.02-1.22)$ \\
\hline & HW & 1.06 & $1.024 \pm 0.075(0.92-1.12)$ \\
\hline & SL & 0.95 & $0.876 \pm 0.047(0.80-0.94)$ \\
\hline & PNW & 0.79 & $0.704 \pm 0.059(0.60-0.76)$ \\
\hline & FW & 0.41 & $0.334 \pm 0.031(0.28-0.36)$ \\
\hline & FLW & 0.52 & $0.508 \pm 0.067(0.38-0.56)$ \\
\hline & PL & 0.48 & $0.524 \pm 0.036(0.46-0.56)$ \\
\hline & PW & 0.39 & $0.304 \pm 0.023(0.26-0.34)$ \\
\hline & PH & 0.46 & $0.380 \pm 0.027(0.34-0.40)$ \\
\hline & PPL & 0.39 & $0.394 \pm 0.013(0.36-0.40)$ \\
\hline & PPW & 0.63 & $0.438 \pm 0.035(0.38-0.50)$ \\
\hline & PPH & 0.65 & $0.432 \pm 0.033(0.38-0.46)$ \\
\hline & ESL & 0.40 & $0.424 \pm 0.049(0.36-0.50)$ \\
\hline & ESD & 0.62 & $0.538 \pm 0.050(0.48-0.62)$ \\
\hline & AL & 1.62 & $1.458 \pm 0.102(1.32-1.60)$ \\
\hline \multirow{9}{*}{$\begin{array}{l}\tilde{g} \\
\stackrel{g}{\Xi} \\
\Xi\end{array}$} & $\mathrm{HL} / \mathrm{HW}$ & 1.07 & $1.114 \pm 0.033(1.05-1.17)$ \\
\hline & FW/HW & 0.39 & $0.326 \pm 0.011(0.30-0.34)$ \\
\hline & FLW/FW & 1.25 & $1.518 \pm 0.116(1.33-1.69)$ \\
\hline & $\mathbf{P L} / \mathbf{P H}$ & 1.05 & $1.379 \pm 0.051(1.33-1.50)$ \\
\hline & $\mathbf{P L} / \mathbf{P W}$ & 1.26 & $1.726 \pm 0.090(1.60-1.80)$ \\
\hline & $\mathbf{P W} / \mathbf{H W}$ & 0.36 & $0.298+0.021(0.27-0.33)$ \\
\hline & PPL/PPH & 0.59 & $0.916 \pm 0.065(0.86-1.05)$ \\
\hline & $\mathrm{PPW} / \mathrm{PW}$ & 1.63 & $1.444 \pm 0.121(1.27-1.69)$ \\
\hline & PPW/HW & 0.59 & $0.438 \pm 0.029(0.38-0.47)$ \\
\hline
\end{tabular}

Another question to solve was the caste status of this individual. Apparently, with regard to its size and general appearance, it looked like a worker. Some features, however, and, specifically, the presence of all three ocelli (normally absent in Myrmica workers) and partly developed scutum and scutellum, allow it to be recognised as a gynaecoid mermithergate according to Wheeler's (1928) terminology (S. Csősz, personal comm.). Moreover, the infested individual was larger than each of its non-infested counterparts, i.e. the measured $M$. sabuleti uninfected workers). This, however, cannot represent an argument of great significance as only a nest sample would be conclusive here. Incidentally, it may be pointed out that a certain combination of features of the specimen under discussion, namely the structure of the alitrunk in connection with the widened petiole and postpetiole, resembles the 'inquiline syndrome' characteristic of many socially parasitic Myrmica species (see e.g. Radchenko \& Elmes 2003). On the other hand, however, a widened petiole and postpetiole are among the most characteristic morphological malformations identified in mermithised workers of M. rubra (Czechowski et al. 2007).

In this context, one should refer to Csösz's (2008) figure of the origin of mermithised morphs in Myrmica species, based on comparative biometrical analysis. He holds that, of female individuals infested by mermithids while in their larval stage, only gyne-destined larvae have a chance of completing their development and becoming imagos, as only such larvae obtain enough nutrient reserves to survive the infestation injury. They also state that, depending on the timing of the infestation, alternative female morphs can develop: early larval infestation gives rise to mermithergates (strictly worker-like individuals) and late larval infestation produces gynaecoid mermithergates (clearly intercaste individuals). Csősz (2008) leans towards the conjecture that there are two well-defined alternative patterns of 
mermithid phenology (i.e. initiation of mermithid larval development) which result in two well-distinguishable morphs of infected individuals. It is also possible, however, that there is no strict borderline between these two periods of infestation, and, consequently, all transitional forms are thinkable.

In the light of the above, the three-ocelled M. sabuleti specimen under discussion might be recognised as a "late mermithergate/early gynaecoid mermithergate". Previously described mermithised individuals of M. rubra (Czechowski et al. 2007), although strikingly morphologically altered, were undoubtedly mermithergates, despite the fact that one of them had one (median) ocellus.

Mermithisation gives rise to abnormal ant morphs that often resemble ergatoid gynes, all the more so with their distended gasters. Bearing in mind that taxonomically significant morphological details, such as sculpture, pubescens, and body proportions also happen to be strikingly altered, one can mistake such a mermithised specimen even for an ergatogyne of an unknown species. This possibility appears to be confirmed by the case of Myrmica myrmecophila Wasm., a species described on the basis of a single female individual found in a nest of M. sulcinodis Nyl. (Wasmann 1910). Van Boven (1970) guessed it to be an ergatoid gyne of the latter species, and then Radchenko \& Elmes (2003), who investigated the holotype specimen, recognised it as a mermithised worker (mermithergate) of $M$. sulcinodis. In the light of Csősz's (2008) recent findings, it actually ought to be regarded as a mermithised $M$. sulcinodis gyne, with strikingly worker-like morphology stunted by parasitism.

In this situation, we can but repeat our recommendation from the earlier paper (Czechowski et al. 2007) that descriptions of possible new ant species should be accomplished with considerable caution, especially when such descriptions are made on the basis of single individuals and the colony of origin of such an untypical individual is unknown. This is all the more important because profound and complex alterations of ant morphology can be caused not only by mermithid nematodes, but also by other internal parasites (see e.g. Passera 1975, Espadaler \& Riasol 1983).

The results obtained in the Pieniny Mts, where three mermithised Myrmica species, $M$. rubra (Czechowski et al. 2007), M. rugulosa and $M$. sabuleti (the present paper), were found in the same location and the same time, suggest that the mermithid nematodes are not narrowly host specific and if they occur on a site, they are able to infect several related ant species which exhibit similar lifecycles. Also it is an important fact that all three species of infected ants were seen to be active outside their nests. This seems to be the first observation for infected Myrmica individuals walking alone, shedding quite some light on how mermithid nematodes might distribute.

\section{ACKNOWLEDGEMENTS}

We are indebted to Sándor Csősz, who read critically an earlier draft of this paper and provided several corrections and valuable comments to the manuscript, and then improved it more as a referee. The paper benefited greatly also from a review by the second referee, Bálint Markó. We also thank Magdalena Kowalewska for taking, and Anna Stankiewicz for technical processing of the SEM photos of the infested and non-infested $M$. sabuleti specimens, and Piotr Ślipiński for taking colour photos of the infested M. rugulosa male. This paper has been prepared as part of a research project sponsored by the Ministry of Science and Higher Education, Warsaw - Grant No. 2P04C 06429 assigned to A. Radchenko. 


\section{REFERENCES}

CSösz S. 2008. Underlying developmental mechanisms of alternative parasitogenic ant phenotypes (Insecta: Hymenoptera: Formicidae). (in prep.).

CZECHOWSKI W., RADCHENKO A. \& CZECHOWSKA W. 2002. The ants (Hymenoptera, Formicidae) of Poland. Museum and Institute of Zoology PAS, Warszawa, $200+1 \mathrm{pp}$.

CZECHOWSKI W., RADCHENKO A. \& CZECHOWSKA W. 2007. Mermithid infestation strikingly alters the morphology of Myrmica rubra (L.) (Hymenoptera: Formicidae): possible taxonomical involvements. Annales Zoologici 57: 325-330.

ESPADALER G. X. \& Riasol J. M. 1983. Cisticercoides de Cyclophyllidea en hormigas Leptothorax Mayr. Modificaciones morfologicas y etologicas del huesped intermediario. Revista Ibérica de Parasitología 43: $219-227$.

GösSWALD K. 1929. Mermithogynen von Lasius alienus gefunden in der Umgebungen von Würzburg. Zoologischer Anzeiger 84: 202-204.

GösswALD K. 1930. Weitere Beiträge zur Verbreitung der Mermithiden bei Ameisen. Zoologischer Anzeiger 90 : $13-21$.

GÖSSWALD K. 1938. Über bisher unbekannte, durch den Parasitismus der Mermithiden (Nemat.) verursachte Formveränderungen bei Ameisen. Zeitschrift für Parasitenkunde 10: 138-151.

HAGMEIER A. 1912. Beitrage zur Kenntnis der Mermithiden. I. Biologische Notizen und systematische Bechreibung einiger alter und neuer Arten. Zoologische Jahrbücher. Abteilung für Systematic, Geographie und Biologie der Tiere 32: 521-612.

HEINZE J. 1998. Intercastes, intermorphs, and ergatoid queens: who is who in ant reproduction? Insectes Sociaux 45: 113-124.

KLOFT W. 1949. Über den Einfluss von Mermisparasitismus auf den Stoffwechsel und die Organbildung bei Ameisen. Zeitschrift für Parasitenkunde 14: 390-422.

KLOFT W. 1950. Ökologischen Untersuchungen zur Verbreitung der Mermithiden bei Ameisen. Zoologische Jahrbücher. Abteilung für Systematic, Ökologie, Geographie und Biologie der Tiere 78: 526-530.

KUTTER H. 1958. Über Modificationen bei Ameisenarbeiterinnen, welche durch den Parasitismus von Mermithiden (Nematod.) verursacht worden sind. Mitteilungen der Schweizerischen Entomologischen Gessselschaft 31: 313-316.

PASSERA L. 1974. Présence d'Hexamermis sp. (Nematoda, Mermithidae) dans les reines vierges et les males de la fourmi Pheidole pallidula Nyl. (Formicidae, Myrmicinae). Bulletin de la Société Zoologique de France 99: 315-324.

PASSERA L. 1975. Les fourmis hôtes provisoires ou intermédiaires des helminthes. Année Biologique 14: 227-259.

PASSERA L. 1976. Origine des intercastes dans les sociétés de Pheidole pallidula (Nyl.) (Hymenoptera Formicidae) parasités par Mermis sp. (Nematoda Mermithidae). Insectes Sociaux 23: 559-575.

RADChENKo A. G. \& Elmes G. W. 1998. Taxonomic revision of the ritae species-group of the genus Myrmica (Hymenoptera, Formicidae). Vestnik Zoologii 32: 3-27.

RADCHENKo A. G. \& Elmes G. W. 1999. Ten new species of Myrmica (Hymenoptera, Formicidae) from the Himalaya. Vestnik Zoologii 33: 27-46.

RADCHENKO A. \& ELMES G. W. 2003. A taxonomic revision of the socially parasitic Myrmica ants (Hymenoptera: Formicidae) of the Palaearctic region. Annales Zoologici 53: 217-243.

RADCHENKO A. G. \& Elmes G. W. 2004. Taxonomic notes on the scabrinodis-group of Myrmica species (Hymenoptera, Formicidae) living in eastern Europe and western Asia, with a description of a new species from Tien Shan. Proceedings of the Russian Entomological Society 75: 222-233.

VAN BOVEN J. K. A. 1970. Myrmica faniensis, une nouvell espece parasite. Bulletin et Annales de la Société Royale Entomologique de Belgique 106: 127-131.

VANDEL A. 1930. La production d'intercastes chez la fourmi Pheidole pallidula sous l'action des parasites du genre Mermis. 1. Étude morphologique des individus parasités. Bulletin Biologique de la France et de la Belgique 64: 457-494.

WASMANN E. 1910. Nachträge zum sozialen Parasitismus und der Sklaverei bei Ameisen. Biologisches Zentralblatt 30: 515-524.

WHEELER W. M. 1928. Mermis parasitism and intercastes among ants. Journal of Experimental Zoology 50: $165-237$.

WHEELER W. M. 1937. Mosaics and other anomalies among ants. Harvard University Press, Cambridge, MA, $95 \mathrm{pp}$. 


\section{STRESZCZENIE}

[Parazytogeniczne deformacje morfologiczne mrówek Myrmica rugulosa Nyl. i Myrmica sabuleti Mein. (Hymenoptera: Formicidae) zarażonych nicieniami $z$ rodziny Mermithidae]

Nicienie z rodziny Mermithidae są wewnętrznymi pasożytami mrówek. Mrówki zarażone w stadium larwalnym, które zdolają zakończyć metamorfozę, odznaczają się często daleko posuniętymi zmianami budowy ciala, nierzadko obejmujacymi ważne cechy taksonomiczne. Zaatakowane przez nicienie osobniki żeńskie moga przybierać rozmaite formy pośrednie (międzykastowe). W pracy opisane sa znalezione $w$ Pieninach spasożytowane przez Mermithidae samce, tzw. mermitanery, Myrmica rugulosa Nyl. (ze szczatkowymi skrzydlami) i robotnicoksztaltny osobnik żeński $M$. sabuleti Mein., rozpoznany jako gynekoidalny mermitergat (wg klasyfikacji i terminologii Wheelera 1928). Informacja ta jest pierwszym doniesieniem o przypadku 'mermityzacji' samców $M$ rugulosa, a zarazem drugim dotyczacym samców z rodzaju Myrmica Latr. w ogóle, i pierwszą informacja o 'mermityzacji' $M$. sabuleti. Morfologię spasożytowanych osobników każdego z gatunków porównano - przy użyciu standardowych pomiarów i wskaźników biometrycznych $-\mathrm{z}$ morfologią ich zdrowych odpowiedników (samców $M$ rugulosa i robotnic $M$. sabuleti). Mermitogeniczne modyfikacje budowy ciała mrówek przedyskutowano w kontekście domniemanych okoliczności ich powstawania (zob. Csösz 2008) oraz - w nawiazaniu do analogicznej wcześniejszej pracy o $M$ rubra (L.) (Czechowski et al. 2007) - ich możliwych implikacji taksonomicznych. Znalezienie w tym samym czasie (sierpień 1977 r.) i miejscu (Wąwóz Gorczyński) zainfekowanych osobników trzech różnych gatunków Myrmica, M. rubra (zob. Czechowski et al. 2007), $M$ rugulosa i $M$. sabuleti (obecne dane), sugeruje, że nicienie Mermithidae nie sa specyficzne wobec gatunku gospodarza i moga atakować kilka pokrewnych gatunków o podobnej biologii. $\mathrm{Z}$ kolei stwierdzenie pozagniazdowej aktywności wszystkich tych zainfekowanych mrówek jest istotną przesłanką na temat sposobu rozprzestrzeniania się pasożyta. 